\title{
Abject Outcasts: Defining Oneself as an Outsider in the Northern Ireland Punk Subculture
}

Parias par choix: se définir comme marginal sur la scène punk nord-irlandaise

\section{Timothy Heron}

\section{(2) OpenEdition}

\section{Journals}

Electronic version

URL: https://journals.openedition.org/rfcb/8207

DOI: $10.4000 /$ rfcb.8207

ISSN: 2429-4373

\section{Publisher}

CRECIB - Centre de recherche et d'études en civilisation britannique

Electronic reference

Timothy Heron, "Abject Outcasts: Defining Oneself as an Outsider in the Northern Ireland Punk Subculture", Revue Française de Civilisation Britannique [Online], XXVI-3 | 2021, Online since 14 December 2021, connection on 04 January 2022. URL: http://journals.openedition.org/rfcb/8207 ; DOI: https://doi.org/10.4000/rfcb.8207

This text was automatically generated on 4 January 2022.

Revue française de civilisation britannique est mis à disposition selon les termes de la licence Creative Commons Attribution - Pas d'Utilisation Commerciale - Pas de Modification 4.0 International. 


\title{
Abject Outcasts: Defining Oneself as an Outsider in the Northern Ireland Punk Subculture
}

\author{
Parias par choix: se définir comme marginal sur la scène punk nord-irlandaise
}

\author{
Timothy Heron
}

\section{Introduction}

1 In 1976, punk took the United Kingdom by surprise, and for one brief moment, challenged many of the cultural and social assumptions of British society, shocking public opinion and causing an outbreak of moral panic in its wake. In Northern Ireland people were preoccupied with other problems. 1976 was the year when internees of the Maze prison started a blanket protest after losing their status as political prisoners; the Shankill Butchers prowled the streets of Belfast in search of Catholic victims; a mother decided to establish the Peace People organization after witnessing the deaths of three children, run over by a fugitive IRA member. In 1976, a total of 297 people lost their lives because of the conflict. All the news reports about Northern Ireland that year seemed to indicate that it truly was "Anarchy in the UK".

2 The phase of the Northern Ireland conflict known as the "Troubles", which began in the mid to late 1960s and ended in 1998 with the Good Friday Agreement, claimed almost 4,000 lives ${ }^{1}$ and bitterly divided the Catholic and Protestant communities. ${ }^{2}$ It also had a significant impact on the cultural life of the region. The outbreak of the conflict hit Northern Ireland's two cultural hubs, Belfast and Derry, disproportionately, and urban cultural life came to a standstill almost overnight. Neighbourhoods became increasingly segregated as Catholics and Protestants, who had often co-existed peacefully in the years before the conflict began, chose to or were forced to move and live among their co-religionists. The construction of "peace lines" materialised the division between the two communities. People seldom left their neighbourhoods at night, fearing for their safety, and in Belfast the few people willing to venture into the 
city were met with iron fences which were raised around the centre and locked at six o'clock. With a lot of pubs and cinemas now inaccessible, nightlife was mostly restricted to the balls and cabarets which were held in hotels outside of the city. Bus services stopped early, so these venues were out of bounds for people with no car at their disposal, and the type of entertainment that they provided was not geared towards young audiences hungry to experience the latest developments in pop music and for whom traditional or country music held little appeal. Thus teenagers were not only faced with the boredom and joblessness that they shared with their peers in Britain, they also had to deal with sectarianism, violence, lack of opportunities, and a severely underdeveloped cultural infrastructure. It is in this context that punk emerged, raising "a two-fingered salute to the grim order of life in a divided society". ${ }^{3}$ This paper seeks to discuss some of the features of punk which enabled participants in Northern Ireland to deliberately cast themselves as outsiders, notably by discussing the role that the abject and horror played in distancing punk from the dominant culture and how this divergence from the mainstream was entrenched by constructing and maintaining strict boundaries between the punk subculture and the wider society.

\section{A cross-community phenomenon}

3 Musically speaking, punk was an aggressive, fast and minimalist subgenre of rock which appeared in the bars of Manhattan in the 1970s. Greatly indebted to 1960s American garage rock and early 1970s bands such as the Stooges, MC5 and the New York Dolls, punk was also influenced by 1960s British beat music, glam rock and pub rock. But it was more than a music genre: it was a cultural phenomenon which spanned several media-fashion, the visual arts, even literature-and, in the United Kingdom at least, emerged as the most visible youth subculture of the era. In London punk acquired a more working-class image than its American counterpart and the new subculture quickly spread to other regions of the country, often following local performances by the Sex Pistols and other early punk acts.

4 Punk found its way to Northern Ireland thanks to word of mouth, to the music press (NME, Sounds, Melody Maker), television programmes (Top of the Pops, The Old Grey Whistle Test) and John Peel's late evening show on BBC Radio One. Local rock bands RUDI (from Belfast) and The Undertones (from Derry) turned to punk after discovering the Ramones on Peel's show. They were soon followed by Stiff Little Fingers, formerly a rock covers band, and newly-formed bands such as the Outcasts, Ruefrex, Protex, Victim and scores of others. Bands and individual punks alike clustered around what in 1976 was Belfast's only independent record shop, Caroline Music. The first punk concerts were given at The Trident in the coastal town of Bangor in 1977, at The Casbah in Derry (where The Undertones soon became a fixture), and in the function rooms of hotels and community centres on the outskirts of Belfast. In 1977, Caroline Music's owner and manager, Kyle Leitch, helped opened the doors of The Pound to pub rock, and, at the start of 1978, to punk. The Pound was a seedy bar close to Belfast city centre but it was one of the few to stay open at night, and, crucially, one of the only venues to allow bands to play original songs rather than covers. The Harp, a similarly disreputable bar, soon followed suit. Terri Hooley, the manager of Good Vibrations, an independent record shop which opened its doors in 1977, took several local bands under his wing and created what was to become the region's most influential 
independent label, which released singles by the Undertones, RUDI, the Outcasts and others. Both Leitch and Hooley helped promote local bands and provided material aid to aspiring musicians and so, unsurprisingly, their record shops, along with The Pound and The Harp, became the epicentre of the Northern Ireland punk scene. Significantly, they became some of the few spaces in Northern Ireland where young people could meet and socialise without having to worry about their ethno-national identity, class, age, and to a certain extent, gender and sexual orientation. The rather apolitical nature of the first wave of punk-or, at least, its suspicion of established ideologies of any variety-enabled local politics to take a back seat.

Although the degree of harmony among punks must not be exaggerated, ${ }^{4}$ the fact remains that despite initiatives led by government bodies and religious organisations to improve community relations in Northern Ireland, ${ }^{5}$ prolonged cross-community interaction was a rare occurrence in Northern Irish society. Together with boxing, greyhound racing, and the Belfast gay scene, punk was one of the few cultural phenomena which fostered amicable cross-community relationships. This set punks outside the mainstream of Northern Irish society. But not only did their behaviour mark them out, punk discourse sought to present the subculture as being antiestablishment. Contrary to the hippie subculture from which it inherited some traits, punk at first had no clearly identifiable political agenda and prided itself in its cynicism. In the early 1980s punk would become politicized following its splintering into "micro-cultures", ${ }^{6}$ with on one side left-leaning anarcho-punk and hardcore scenes and on the other white power bands and the racist skinhead scene, which in Northern Ireland had links with the loyalist Ulster Freedom Fighters. However, for most of the 1970s punk claimed allegiance to no political ideology. Bands initially preferred to voice their discontent in general terms, the Clash being the earliest and most notable exception.

Sometimes accused of nihilism, the early punks' attitude has been more accurately described my rock journalist Greil Marcus as negationist. While "nihilism means to close the world around its own self-consuming impulse, negation is the act that would make it self-evident to everyone that the world is not as it seems". ${ }^{7}$ In Northern Ireland what punks negated was the taboo placed on cross-community interaction as well as the obligation of taking part in the process of cultural reproduction of the communities they belonged to. And yet, punks' "non-conformism, as they understood it, was an existential and aesthetic rather than a political statement". ${ }^{8}$

\section{A Celebration of the Abject}

7 The provocative acts of the Sex Pistols - notably their swearing on a live chat show on a local London television channel in December 1976 and their boat trip on the Thames on the day of the Jubilee of Queen Elizabeth II to promote their single "God Save the Queen" in June 1977 - were opportunities used by the media to whip up a moral panic about the emerging phenomenon. They focused on the unconventional style and behaviour of punks, exaggerating the scene's violence and its most sensationalist aspects and described the subculture in terms evoking the abject ("unpleasant", "sick and filthy", "degenerate", "revolting", "repugnant"). ${ }^{9}$ In common parlance, the abject refers to that which is vile and inspires disgust; etymologically, it signifies the state of being cast off and degraded. For Julia Kristeva, the abject is more than a "jettisoned 
object": it not only has the quality of being opposed to the "I", it is "something" that the "I" does not recognize as a thing. It draws one "toward the place where meaning collapses". ${ }^{10}$ It defies categorization; it disturbs order and meaning. It is "not lack of cleanliness or health that causes abjection but what disturbs identity, system, order. What does not respect borders, positions, rules. The in-between, the ambiguous, the composite". ${ }^{11}$

Although the media frenzy was short-lived, the description of punk as abject had longterm effects, as it framed punk's reception by the wider society, including in Northern Ireland: "Everyone hated us then; punks were seen as scum of the earth to the normal society. More so than the scum that were killing and bombing innocent people; [it] was really strange". ${ }^{12}$ The framing of punk as abject also played a part in shaping the meaning of the phenomenon for punks themselves, as the representations circulating in the media were sometimes the only ones accessible to aspiring punks: the abject thus became firmly associated with the subculture. Indeed, "vomit, snot, spitting, menstrual blood, fetishism, obscenity, perversion, violence, unreason" ${ }^{13}$ were used as inspiration for the names of Northern Irish punk bands (the Outcasts, Victim, the Defects, Stalag 17, Stage B, Toxic Waste...) and album art (the sleeve of Rudi's 1978 single "Big Time" featured a zombie-like monster). The abject was seized upon by punks as a means of casting themselves as outsiders and became an integral and enduring aspect of punk iconography and discourse. We shall now see how the abject was represented through dress style and through the lyrics of punk songs.

\section{Punk Dress: an Abject Style}

9 People generally encountered punk dress before hearing punk rock, not only because of limited airplay on radio stations, but because punks appeared in the streets before the first singles or albums were pressed: thus punk's initial shock was visual. Punk dress ${ }^{14}$ has a complex genealogy, but its most recognisable form emerged from the crosspollination of entrepreneurs and designers Malcolm McLaren and Vivienne Westwood and an art school milieu nicknamed "the Bromley Contingent" which converged around the Sex Pistols and the couple's Sex/Seditionaries boutique on London's King's Road in $1976 .{ }^{15}$ The dress style was picked up by the broadcast media and immediately associated with punk rock. A less art-school, more street-orientated style emerged as young people across the isles drew inspiration from these images to construct their own punk dress in their own contexts, but several features were to be found in all scenes: punks generally favoured black, red and metallic colours over brown, yellow and pastel colours, and tight-fitting garments and angular, harsh lines over wide, flowing clothes ${ }^{16}$ which were still popular in the late 1970s. in contrast to the prevailing post-hippie trend of natural beauty, ${ }^{17}$ faces were pale rather than tanned, hair was chopped short and dyed in bright colours, and heavy make-up was worn by young women and occasionally by young men. The punk dress was thus deliberated assembled to contrast sharply with contemporary style.

10 In order to further stress this divergence from mainstream fashion, punks borrowed from earlier and contemporary subcultures which were considered to be deviant: $\mathrm{Dr}$ Martens boots from the skinheads, "drainpipe" trousers and brothel creeper shoes from the teddy boys, studded leather jackets from the rockers or bikers of the 1950s, and bondage gear from alternative sexual subcultures which in the 1970s were still 
mostly associated with queer communities, such as leather or PVC fetishism communities and BDSM subcultures Adopting clothing items and accessories associated with these groups inevitably coded punk as deviant and signalled their apparent opposition to the values of the dominant culture:

Deviancy has a dissident side; it challenges the clarity of the symbolic universe. Deviants are seen either as outsiders, recognized as having left the communal, symbolic universe, or else, as with immigrants, they are ascribed to as outsiders who participate in another symbolic universe which originated in a different culture..$^{18}$

11 Because of its adversarial aesthetic, Dick Hebdige has argued that punk was the subculture that best dramatized what had come to be called "Britain's decline". Indeed, punks appropriated the era's rhetoric of crisis and anarchy ${ }^{19}$ and thus tapped into contemporary fears (mass unemployment, crime, immigration, totalitarianism, evolving moral standards, etc.) by presenting themselves as "degenerates". ${ }^{20}$

This was also conveyed through abjectification of the body or, in other words, the process of subverting contemporary norms of beauty and decorum. With punk it seemed that the body and its excessive physicality were both celebrated and loathed: "the uglier you were, the more true to the punk spirit you were". ${ }^{21}$ At any rate, it put the body on display, warts and all. Young people who did not match the beauty ideals of glossy magazines wore clothes which drew attention to the body. Overtight trousers, short skirts, underwear worn as outerwear, oversized coats, pullovers and boots, short spiky hair or asymmetrical hairstyles distorted the body's proportions. Bondage trousers, heavy boots and stiletto shoes forced punks to adopt unnatural postures and gaits. Even in its more subdued manifestations, punk dress expressed distortion and deformity: rips, tears, zips, holes, asymmetrical lines, graffiti, studs, out-of-place objects attached to clothes or to the flesh, etc. Punk seems to have held particular appeal for young people in Northern Ireland who felt that they did not fit in to their families, their communities or to wider society:For anyone in the UK at that point who felt cast out because of class, sexuality, perception, gender, even choice, who felt useless, unworthy, [punk] was an attraction/repulsion machine of [...] infernal power that offered the chance of possible transcendence. In becoming a nightmare, you could find your dreams. ${ }^{22}$

Some punks went to great lengths to theatricalize the abject in their dress, bodies and practices. Safety pins were pushed through earlobes or other body parts; a few punks practised self-mutilation. A much more widespread practise was "gobbing": spitting on band members during performances, a phenomenon which lasted longer in Northern Ireland than in Britain. Through these abject displays, "punk [acted] out a literally violent rejection of mainstream models of identity, as expressed through dominant ideals of bodily decorum". ${ }^{23}$ This rejection was further emphasised by the use of fascist imagery, a practice which has been interpreted both as a quasi-Situationist attempt to demystify the sign and as a generational, adolescent act of provocation, "an anti-mums and anti-dads thing". ${ }^{24}$ Pictures and testimonies reveal that Northern Irish punks, just like their London counterparts, toyed with Nazi symbols (swastikas, surplus German army jackets, the infamous "Destroy" $t$-shirts, which featured a large swastika) and occult imagery (pentangles, upside-down crucifixes, Satanic inscriptions, etc.). ${ }^{25}$ The display on punk bodies of symbols which referenced what Julia Kristeva calls the "abjection of Nazi crime" or which celebrated that which is "immoral, sinister, scheming, and shady" ${ }^{26}$ stemmed from punks' conscious desire to set themselves apart, to mark themselves as outcasts, whether through dress or, as we shall see now, through song. 


\section{Punk Songs: the Power of Horror}

13 fact that it enabled the exploration of a whole new range of themes by anyone able and willing to start a band. Indeed, according to John Mullen, "punk seemed to open the gates to dealing with a much wider variety of themes in popular song, with a particular emphasis on the gritty" ${ }^{27}$. This was due to punk's irreverent, iconoclastic nature, but also to the application of the "DIY ethic" to the practice of music: even people with little means and experience could start a band and play on stage. For the first time in years, young people were able to voice their own views to an audience made of people their own age. In Northern Ireland, punks tackled various social and political issues, romantic and sexual relationships, and aspects of teenage popular culture. ${ }^{28}$ I have spoken elsewhere about how punks in Northern Ireland made few references to the "Troubles" (only a small proportion of songs dealing with social and political issues revolve around the conflict) and about the fact that the celebration in their songs of pleasure and carefree fun constituted a leisure critique of the status quo. ${ }^{29}$ Here I would like to focus on the use of the abject in punk song as a means of signalling their status as deviants and outsiders.

In Northern Ireland as elsewhere, punks delved into aspects of popular culture which, up until then, has previously remained unexplored in rock music. Previous genres had shown interest in high fantasy and space opera: the members of Led Zeppelin were obsessed with J.R.R. Tolkien; Rick Wakeman created concept albums about the Legends of the Round Table and Jules Verne; Marc Bolan, in his pre-glam era, sang about unicorns and dragons. By contrast, punk bands were fascinated by more lurid, sensationalist forms of popular culture: crime fiction, B-movies, horror. ${ }^{30}$ In the US, the Ramones frequently referenced horror films: "Chain Saw" was inspired by Tobe Hooper's Texas Chain Saw Massacre (1974) while "Pinhead" is a nod to Todd Browning's Freaks (1932). The Cramps made camp B-movie iconography the hallmark of their style. In Britain, the Adverts imagined what it would be like to receive the transplant of a pair of eyes formerly belonging to a serial killer ("Gary Gilmore's Eyes"). The clothes designed by Malcolm McLaren and Vivienne Westwood were inspired by the world of pornography and crime (the Cambridge Rapist, the Yorkshire Ripper). The first group of punk singer and guitarist Chrissie Hynde - an American expatriate in London - was called the Moors Murderers, in homage to the serial killer couple Ian Brady and Myra Hindley. ${ }^{31}$ Punks in Northern Ireland shared this fascination and produced songs which can be assimilated to two broad categories of horror: monster movies and slasher films.

Monster movies typically feature nonhuman or other-than-human antagonists, which can range from werewolves (Legend of the Werewolf (1975), An American Werewolf in London (1981)) to zombies (Dawn of the Dead (1978)). ${ }^{32}$ This genre influenced songs about such creatures in the Northern Irish punk scene: the Outcasts sang about zombies ("Clinical Love") and cyborgs ("Cyborg"); "Bewerewolf!" by RUDI features a werewolf. On a psychoanalytical level, monsters are often associated with fear of the changing, mutating adolescent body and repressed sexual desire, ${ }^{33}$ but they may also be read on another level as "transgressors of the social practice, beings that violate accepted cultural codes" ${ }^{34}$ Since the primary context of the reception of these songs, which often feature "unnatural" couplings, was the largely cross-community local punk 
subculture, they remind us that punks were "monsters" in the sense that they threatened to disrupt some of Northern Irish society's accepted cultural codes by revealing the arbitrary nature of the "us/them" binary and by disrupting the process of sectarian othering.

As we have seen, the abject defies categorization, it "disturbs identity, system, order", refuses to "respect borders, positions, rules". ${ }^{35}$ As I have argued elsewhere, the display by punks of the abject in their dress and in their songs drew attention to the fragility of the sectarian boundaries they inhabited; they hinted at the possibility of their transgression. ${ }^{36}$ However, these songs did not constitute a conscious denunciation of sectarianism. Rather, they were a celebration of a form of popular culture that punks considered both enjoyable and which was still considered illegitimate and, sometimes, obscene. Another subgenre of horror which features heavily in Northern Irish punk songs is the slasher film, which typically portrays a killer wielding a bladed weapon. Contemporary examples are The Texas Chain Saw Massacre (1974), Halloween (1978), The Hills Have Eyes (1977) and Friday the 13th (1980). Thus in the song "There Goes Norman" by the Undertones, an unbalanced character, after being rejected by young women, roams around a public park at night, planning to viciously attack passers-by ("He'll poke out your eyes"). "Killer On The Streets" by the Defects also features a murderer on the prowl:

Killer killer killer on the streets

The death skull shining in his eyes

His lust for blood he won't disguise

His mind's diseased there is no cure

In search for those he thinks impure.

17 Stage B's "Lizzie Borden" recounts the crimes of a young American woman accused in 1892 of murdering her father and stepmother with an axe, quoting a $19^{\text {th }}$ century children's rhyme:

Lizzie Borden took an axe

And gave her mother forty wacks

When she saw what she had done

she gave her father forty-one

The Outcasts was the Northern Irish group which took the abject to the extreme. In "Beating and Screaming", the horror is reduced to the gratuitous act of violence itself: the only lyrics are the words included in the title, "beating" and "screaming", repeated several times during the song. The song is punctuated by female screams, probably sampled from a horror movie. In "The Cops are Coming", the narrator kills his girlfriend and then engages in sexual intercourse with her corpse:

I'm glad I killed you babe

I'm glad that you are dead

I'm glad you'll breathe no more

I'm glad there's a knife in your head

'Cause I think I'll make love to your dead body on the bloody floor

19 Perhaps some of these "slasher" songs reflected anxiety about "Troubles"-related violence. After all, sectarian murders were still a reality; most of the members of the notorious Shankill Butchers ${ }^{37}$ were being tried during the heyday of the first wave of Northern Irish punk. This concern seems to appear subconsciously in songs like "Victim" by Rabies:

Dead of night

When it's quiet on the streets 
No one will protect you

In the dead of night. conservative backlash, which anticipated Margaret Thatcher's increasingly conservative stance on moral issues in the 1980s, took prominence in media discourses. In Northern Ireland, the Democratic Unionist Party, linked to Ian Paisley's fundamentalist Free Presbyterian Church, was known for picketing cinemas which screened films it deemed obscene or blasphemous, such as The Exorcist (1973) or Monty Python's Life of Brian (1979). By celebrating in their songs what at best would have been considered vulgar and in poor taste and at worst as obscene and blasphemous, punks deliberately cast themselves in the role of outcasts and deviants. They also set out to entrench their divergence from the mainstream by constructing and maintaining strict boundaries between their subculture and the wider culture.

\section{Authenticity and Subcultural Capital}

While, in theory, anyone could become a punk, admittance into the subculture was not an automatic process, and once one became a member, peer pressure could be considerable. The individual who aspired to join the punk subculture had to know and master a certain number of codes and values, some of which contrasted with the prevailing values of mainstream society. Conformity to these codes revealed the aspiring punk to be more or less authentic. In common parlance, authenticy refers to the spontaneous manifestation and expression of one's self or personality - it implies that what is revealed flows naturally and effortlessly from the individual. And yet, as a sociological concept - and in particular when applied to subcultures - it appears not as a spontaneous phenomenon but as conformity to the hierarchies constructed within a given subculture. These hierarchies are both external and internal: external hierarchies are constructed in contrast to the dominant culture or to other subcultures (punk was "not mainstream" but also "not hippie", "not skinhead", "not disco", etc.). Hierarchies are also set up within the subculture, which requires each of its participants to acquire a certain amount of knowledge and know-how: each punk had to be capable of discerning the goods, information and practices that were valued in their subculture from those that were considered to have little or no value. They had to mobilise them on a daily basis so that the process appeared natural to the other members of the subculture. The concept of authenticity can thus be assimilated to what sociologist Sarah Thornton called "subcultural capital" in a study of rave culture in the early 1990s. ${ }^{41}$ According to Thornton, subcultural capital is a form of social distinction that operates according to the same logic as Bourdieu's concept of cultural capital, ${ }^{42}$ but

Revue Française de Civilisation Britannique, XXVI-3 | 2021 
within a different context: that of subcultures rather than fields where people with large amounts of economic, cultural and social capital operate.

Subcultural capital exists in two forms: it can either be "objectified", for example in the form of subculture-specific haircuts or punk records, or "embodied", which implies being "in the know" and using in-group slang. Whether one draws from the concept of authenticity or subcultural capital, it is clear that one does not become a punk or a member of any other subculture by making a simple profession of faith; membership is not acquired once and for all but is the result of a constant process, a "narrative work of everyday life". ${ }^{43}$ Thus the individual who aspired to join the punk subculture had to integrate a number of external and internal hierarchies and align her or his behaviour with them. These hierarchies were linked to the local context and were part of the lived experience and everyday life of punks: they could vary in time and in space, between subcultures but also between different local scenes within the same subculture. Moreover, they were often difficult to clearly identify or describe since they were perceived and presented as natural and were rarely made explicit. However, it is possible to draw some broad outlines.

The Northern Ireland punk subculture was translocal in the sense that it was inscribed in a local and specific cultural, social, economic, historical and political context, with all that this implies (specific relationship with parents, the local authorities and with members of different ethno-national groups, underdeveloped cultural infrastructures, complex musical genealogy, etc.), but it was also part of a broad cultural phenomenon that, far from being restricted to the British Isles or even to the English-speaking world, reached throughout the Western world and beyond. Local punk scenes were linked to each other by media channels (the music press, fanzines, personal correspondence, the radio, etc.) and commercial networks (the music industry, small entrepreneurs, concert programmers, etc.). Because the punk subculture was a global phenomenon, and because of its proximity to the London scene, the epicentre of European punk, Northern Irish punk drew most of its hierarchies from it. In London and Manchester, as well as in Belfast and Derry, punk differed both from the dominant, mainstream culture, which was widely shared by all because of the hegemony of the mass media, and from other subcultures and popular music phenomena, which appeared in one form or another in most British towns. For example, disco music, soft rock, progressive rock and heavy metal were rejected by punks, as were long hair, facial hair and flared trousers. Within the subculture, internal hierarchies bestowed more authenticity or subcultural capital on some groups than on others. For example, the Sex Pistols and the Clash were considered more "authentic" than Elvis Costello or the Boomtown Rats which were considered "new wave". ${ }^{44}$ Boundaries were fluid and often set up arbitrarily: they could therefore be contested by different members of the subculture. A group like The Jam could be seen by some as authentically punk, but by others as a mod band that was taking advantage of the punk phenomenon. However, as a regional and local scene, Northern Irish punk set up its own external and internal hierarchies, which were often variations of those shared in the global punk sphere. Thus showbands ${ }^{45}$ which were still part of the Irish musical landscape of the 1970s in one form or another, were universally despised. The band Stiff Little Fingers, one of the few local groups that had international success, was often criticized by Northern Irish punks for starting out as a heavy metal cover band that opportunistically decided to embrace punk. Moreover, in Northern Ireland as elsewhere, punk stressed the local: 
regional accents and local references in the lyrics rather than the transatlantic accent used by pop singers and references to a mythical America. This was not only a rejection of the dominant American culture ("Stuff the USA" sang the Rip-Offs ${ }^{46}$ ) but it also conveyed its ambiguous relationship with London, which on one hand was held up as a point of reference, a sort of punk Mecca, and a springboard for emerging talents many bands relocated or aimed to relocate to the capital - and on the other was perceived as a rival scene which needed to be outdone. London and England were therefore the symbols of a punk "mainstream" against which Northern Irish punks aimed to build their own identity and measure their own authenticity. Northern Irish punks would claim that they experienced on a daily basis a reality that London punks could only imagine in their lyrics (anarchy, inter-community violence, lack of opportunities linked to the conflict, etc.). They claimed that punk, which they dismissed as being little more than a fad in London, had a real raison d'être in Northern Ireland. This was compounded by the traditional provincial distrust of the metropolis and Irish contempt for anything that seems to amount to ostentatiousness or "showing-off". Young people in Northern Ireland who wished to identify as punks therefore needed to know and integrate the norms defined by the hierarchies that delineated the boundaries of the subculture both globally and in their own locality. Participation in the Northern Irish punk scene thus required an act of double distancing: both from the wider dominant culture and from the London punk "mainstream".

\section{Conclusion}

In a deeply divided society, where affiliation with one of two rival ethno-national groups was a prerequisite for social integration, where sectarian partisanship and social conformity were the norm, punk constituted a "cumulative fuck you to the violence and social conservatism that dominated everything everywhere. Empowerment, escape and energy that the older generations (even those in their 20s) just couldn't understand". ${ }^{47}$ Northern Irish punks, proud to take part in a subculture which provided a temporary escape from the "Troubles" and allowed them to transgress the taboo of cross-community interaction, signalled their status as deviants and outsiders by celebrating the abject in their dress style and in song. They deliberately cast themselves as non-conformists and actively sought to distance themselves from the mainstream by constructing strict boundaries, the existence of which depended on the conformity to hierarchies set up within the subculture in order to safeguard punk authenticity.

\section{BIBLIOGRAPHY}

Bourdieu, Pierre, and Passeron, Jean-Claude, La Reproduction. Éléments pour une théorie du système d'enseignement (Paris, Editions de Minuit, 1970). 
Bourseiller, Christophe, and Penot-Lacassagne, Olivier, Contre-Cultures (Paris, CNRS éditions, 2013).

Cobley, Paul, 'Leave the Capitol' in Roger Sabin (ed.), Punk rock, so what? the cultural legacy of punk (London, Routledge, 2009).

Brake, Mike, Comparative Youth Culture: The Sociology of Youth Cultures and Youth Subcultures in America, Britain and Canada (New York, Taylor and Francis, 2003).

Colegrave, Stephen, and Sullivan, Chris, Punk (London, Bounty, 2013).

Crossley, Nick, Networks of Sound, Style and Subversion : the Punk and Post-punk Worlds of Manchester, London, Liverpool and Sheffield, 1975-1980 (Manchester, Manchester University Press, 2015).

De Coning, Alexis, 'Sympathising with a Monster: An Exploration of the Abject "Human Monster" in Iain Banks' “The Wasp Factory”', in Elizabeth Nelson (ed.), Creating Humanity, Discovering Monstrosity: Myths \& Metaphors of Enduring Evil? (Oxford, Inter-Disciplinary Press, 2010), pp. 163-173.

Ellis, Jim, Derek Jarman's Angelic Conversations (Minneapolis, U of Minnesota, 2009).

Etchart, Joana, 'Path dependency in policy-making in Northern Ireland: the first community relations policies in 1969-1974', Irish Political Studies $31 \mathrm{n}^{\circ} 4$ (2016), pp. 567-588.

Fay, Marie-Therese, Morrissey, Mike, and Smyth, Marie, Northern Ireland's Troubles: The Human Costs (London, Pluto Press, 1999).

Force, William Ryan. 'Consumption Styles and the Fluid Complexity of Punk Authenticity', Symbolic Interaction $32 \mathrm{n}^{\circ} 4$ (2009), pp. 289-309.

Foucault, Michel, Les Anormaux : cours au Collège de France (1974-1975) (Paris, Seuil Gallimard, 1999). Heron, Timothy, “'Alternative Ulster"': Punk and the Construction of Everyday Life in 1970s Northern Ireland', Imaginaires 19 (2015).

Heron, Timothy, 'Le punk en Irlande du Nord (1976-1983)', (PhD dissertation, University of Reims Champagne-Ardennes, 2017).

Heron, Timothy, “'We're Only Monsters”: Punk Bodies and the Grotesque in 1970s Northern Ireland', Études irlandaises 42.1 (2017).

Hebdige, Dick, Subculture: the Meaning of Style (London, Methuen, 1979).

Hooley, Terri, and Sullivan, Richard, Hooleygan: Music, Mayhem, Good Vibrations (Belfast, Blackstaff Press, 2010).

Kristeva, Julia, and Roudiez, Leon S, Powers of Horror: An Essay on Abjection (New York, Columbia UP, 1982).

Laing, Dave, One Chord Wonders: Power and Meaning in Punk Rock (Oakland, PM Press, 2015).

Marcus, Greil, Lipstick traces: A Secret History of the Twentieth Century (London, Faber, 2011).

McDonald, Henry, Colours: Ireland: From Bombs to Boom (Edinburg, Mainstream Pub., 2005).

Misiroglu, Gina, American Countercultures: An Encyclopedia of Nonconformists, Alternative Lifestyles, and Radical Ideas in U.S. History, (New York, Routledge, 2015).

Mullen, John, 'UK Popular Music and Society in the 1970s', Revue française de civilisation britannique $11 \mathrm{n}^{\circ} 3$ (2016). 
O'Connor, Nuala, Bringing It All Back Home: The Influence of Irish Music at Home and Oversea (Dublin, Merlin, 2001).

Sandbrook, Dominic, Seasons in the Sun: the Battle for Britain, 1974-1979 (London, Penguin, 2013).

Savage, John, England's Dreaming: Sex Pistols and Punk Rock (London, Faber \& Faber, 2005).

Sklar, Monika, Punk Style, (Oxford, Berg, 2013).

Thornton, Sarah, 'The Social Logic of Subcultural Capital', in Ken Gelder (ed.), The Subcultural Reader (London, Routledge, 1997), pp. 200-209.

\section{Discography}

Battle of The Bands. Good Vibrations, 1978, 2 x 45 rpm.

Belfast Rock. Rip Off Records, 1978, 331/3 rpm.

Made In Ulster - The Best of NI Punk Vol. 1, NI Punk, 2011. Online compilation.

The Defects. Defective Breakdown. WXYZ Records, 1983, 3311/3 rpm.

Good Vibrations - The Punk Singles Collection. Anagram Records, 1994, compact disc.

The Outcasts. Self Conscious Over You. Good Vibrations, 1979, 3311/3 rpm.

The Ramones. The Ramones. Sire, 1976, 331/3 rpm.

Rudi. “When I Was Dead.” Jamming!. 1981, 45 rpm.

Shellshock Rockers. Spit Records, 2012, compact disc.

The Undertones. Hypnotised. Sire, 1980, 331/3 rpm.

\section{NOTES}

1. For a discussion of the estimates of the number of "Troubles"-related deaths, Marie-Therese Fay, Mike Morrissey, and Marie Smyth, Northern Ireland's Troubles: The Human Costs (London, Pluto Press, 1999), pp. 121-132.

2. With political and religious roots which reached far back in time, the "Troubles" involved paramilitaries, politicians, members of the British security forces and ordinary citizens. Society was divided into two opposing ethno-national groups, seemingly trapped in a deadlock because of their irreconcilable aspirations. The unionists-loyalists, most of whom identified as Protestant, wanted the region to remain a part of the United Kingdom, were attached to the British Crown and to a sense of Britishness, and had developed a siege mentality after centuries of living on the island as a privileged minority. The nationalists-republicans, most of whom identified as Catholic, wanted to put an end to the institutionalised discrimination they faced and wished for the establishment of an island-wide Irish republic.

3. Henry McDonald, Colours: Ireland: From Bombs to Boom (Edinburg, Mainstream Pub., 2005), p. 60.

4. The participants themselves admit that not all punks were non-sectarian (see Terri Hooley and Richard Sullivan, Hooleygan: Music, Mayhem, Good Vibrations (Belfast, Blackstaff Press, 2010), p.42). Several incidents revealed how fragile cross-sectarian unity could be. For instance, when The Clash's Joe Strummer started sporting an H-Block t-shirt in support of the Republican hunger strikers in the Maze prison, he offended a large part of his Protestant fans. Yet these incidents were few and far between. 
5. In her discussion of official Community Relations policies in Northern Ireland in the 1970s, Joana Etchart argues that after the reintroduction of Direct Rule in 1974, "the relationship between public bodies and the community at large became distant and centred on the needs of the administration" rather than engaging with actors within the community (Joana Etchart, 'Path dependency in policy-making in Northern Ireland: the first community relations policies in

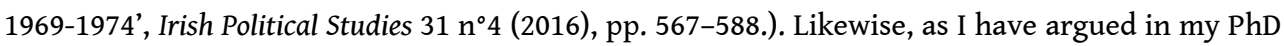
thesis, the strategies carried out by religious organisations (such as the Corrymeela Community on the north coast and the Colombanus Community of Reconciliation, the Cornerstone Community, the Curragh Community and others in Belfast) generally failed to address the desires of individuals (and especially young people) living in working-class areas (Timothy Heron, 'Le punk en Irlande du Nord (1976-1983)', (PhD dissertation, University of Reims ChampagneArdennes, 2017).

6. For a discussion of subcultures, counter-cultures and 'micro-cultures', see Christophe Bourseiller and Olivier Penot-Lacassagne, Contre-Cultures (Paris, CNRS éditions, 2013).

7. Greil Marcus, Lipstick traces: A Secret History of the Twentieth Century (London, Faber, 2011), p. 8.

8. Nick Crossley, Networks of Sound, Style and Subversion : the Punk and Post-punk Worlds of Manchester, London, Liverpool and Sheffield, 1975-1980 (Manchester, Manchester University Press, 2015), p. 54.

9. Dave Laing, One Chord Wonders: Power and Meaning in Punk Rock (Oakland, PM Press, 2015), p. 142. 10. Julia Kristeva and Leon S. Roudiez, Powers of Horror: An Essay on Abjection (New York, Columbia UP, 1982), pp. 1-2.

11. Ibid., p. 4.

12. Gary, survey, 2017. Timothy Heron, 'Le punk en Irlande du Nord (1976-1983)', (PhD dissertation, University of Reims Champagne-Ardennes, 2017).

13. Paul Cobley, 'Leave the Capitol' in Roger Sabin (ed.), Punk rock, so what? the cultural legacy of punk (London, Routledge, 2009), p. 174.

14. For the purpose of this article, I rely on Joanne Eicher's definition of dress: "A system of nonverbal communication that enhances human beings' interaction as they move in space and time. As a coded sensory system, dressing the body occurs when human beings modify their bodies visually or through other sensory measures by manipulating color, texture, scent, sounds, and taste or by supplementing their bodies with articles of clothing and accessories, and jewelry". Monika Sklar, Punk Style, (Oxford, Berg, 2013), p. 8.

15. A similar scene emerged in the seaside resort of Bangor in Northern Ireland: the "Young Americans" were to Northern Ireland what the Bromley Contingent was to London.

16. Ibid., p. 80.

17. As Gina Misiroglu explains, "men wore beards, mustaches, sideburns, and long, unkempt hair. Women did not perm or roll their hair, as was common at the time, and often left their underarms and legs unshaven and went without makeup or bras". Ironically, the adoption by hippies of "natural beauty" was an expression of dissidence against mainstream culture. Gina Misiroglu, American Countercultures: An Encyclopedia of Nonconformists, Alternative Lifestyles, and Radical Ideas in U.S. History, (New York, Routledge, 2015), p. 380.

18. Mike Brake, Comparative Youth Culture: The Sociology of Youth Cultures and Youth Subcultures in America, Britain and Canada (New York, Taylor and Francis, 2003), p. 17.

19. It was not the use of the word "anarchy" by the Sex Pistols and other bands which was shocking, but the fact that punks seemed to welcome and celebrate anarchy. Indeed, the word was used prominently in the media throughout the 1970s. To give just one example, in 1974 The Times described the UK in the following terms: "A world increasingly ruthless and increasingly irrational, a world in which the principle of order is by its nature exposed to furious attack [...]. The vanguard of anarchy is loose in the world". Dominic Sandbrook, Seasons in the Sun: the Battle for Britain, 1974-1979 (London, Penguin, 2013), p.125. 
20. Dick Hebdige, Subculture: the Meaning of Style (London, Methuen, 1979), p. 85.

21. Daniela Soave quoted in Stephen Colegrave and Chris Sullivan, Punk (London, Bounty, 2013), p. 317.

22. Jon Savage, England's Dreaming: Sex Pistols and Punk Rock (London, Faber \& Faber, 2005), p. XV.

23. Jim Ellis, Derek Jarman's Angelic Conversations (Minneapolis, U of Minnesota, 2009), p. 57.

24. Siouxsie Sioux quoted in Jon Savage, England's Dreaming: Sex Pistols and Punk Rock (London, Faber \& Faber, 2005), p. 241.

25. Henry McDonald, Colours: Ireland: From Bombs to Boom (Edinburg, Mainstream Pub., 2005), p. 37.

26. Julia Kristeva and Leon S. Roudiez, Powers of Horror: An Essay on Abjection, New York: Columbia UP, 1982, p. 4.

27. John Mullen, 'UK Popular Music and Society in the 1970s', Revue française de civilisation britannique $11 \mathrm{n}^{\circ} 3$ (2016).

28. An analysis of over two hundred Northern Irish punk songs from the 1976-1983 period reveals that over a third of them tackle various social and political issues; a quarter deal with romantic and sexual relationships; and ten percent are concerned with aspects of teenage pop culture. See Timothy Heron, 'Le punk en Irlande du Nord (1976-1983)', (PhD dissertation, University of Reims Champagne-Ardennes, 2017).

29. Ibid.

30. Various songs from the New wave of British heavy metal, which also emerged in the late 1970s, explore similar themes.

31. Paul Gallagher, 'Steve Strange \& Chrissie Hynde Offen All of England as Punk Band The Moors Murderers, 1978', 20 February 2015, <https://dangerousminds.net/comments/ steve_strange_chrissie_hynde_offend_all_of_england_as_punk_band_the_moors_m $>[15 \quad$ June 2020].

32. Although most members of punk bands in Northern Ireland were teenagers, films given an $X$ certificate (suitable only for anyone aged 18 or over) by the British Board of Film Classification could generally be accessed from 15 or 16 years of age, as local cinemas typically did not enforce a strict age admission policy.

33. See Foucault's discussion of "human monsters" in Michel Foucault, Les Anormaux : cours au Collège de France (1974-1975) (Paris, Seuil Gallimard, 1999), pp. 37-40. For a discussion of the grotesque nature of punk bodies both in dress and in song, see Timothy Heron, “'We're Only Monsters": Punk Bodies and the Grotesque in 1970s Northern Ireland', Études irlandaises 42.1 (2017), pp. 139-154.

34. Alexis De Coning, 'Sympathising with a Monster: An Exploration of the Abject "Human Monster" in Iain Banks' “The Wasp Factory”, in Elizabeth Nelson (ed.), Creating Humanity, Discovering Monstrosity: Myths \& Metaphors of Enduring Evil? (Oxford, Inter-Disciplinary Press, 2010), p. 165.

35. Julia Kristeva and Leon S. Roudiez, Powers of Horror: An Essay on Abjection (New York, Columbia UP, 1982), p. 4.

36. Timothy Heron, “We're Only Monsters”: Punk Bodies and the Grotesque in 1970s Northern Ireland', Études irlandaises 42.1 (2017).

37. The Shankill Butchers were a Belfast gang of loyalists who during the 1970s tortured and murdered over nineteen people, most of them Catholics.

38. Jack, interview, 31 May 2020.

39. A quarter of Northern Irish punk songs deal with romantic and sexual relationships. The irony of punks singing love songs in a conflict-ridden society betrays the fact that despite their affiliation with a subculture which was reputed for its suspicion of romantic love and of commercial culture, many of these young people actually aspired for a life of carefree fun, or at least for a 'normal' adolescent life. They knew that this was something out of their reach, so in their songs they imagined a world where they could concentrate on being teenagers and deal 
with adolescent problems, such as crushes, sex and growing up. See Timothy Heron, “'Alternative Ulster"': Punk and the Construction of Everyday Life in 1970s Northern Ireland', Imaginaires 19 (2015).

40. Dominic Sandbrook, Seasons in the Sun: the Battle for Britain, 1974-1979 (London, Penguin, 2013), pp. 391-407.

41. Sarah Thornton, 'The Social Logic of Subcultural Capital', in Ken Gelder (ed.), The Subcultural Reader (London, Routledge, 1997), pp. 200-209.

42. See Pierre Bourdieu et Jean-Claude Passeron, La Reproduction. Éléments pour une théorie du système d'enseignement (Paris, Editions de Minuit, 1970).

43. William Ryan Force, 'Consumption Styles and the Fluid Complexity of Punk Authenticity', Symbolic Interaction $32 \mathrm{n}^{\circ} 4$ (2009), p. 290.

44. As John Mullen states: "whether or not a given group was "really" punk has produced many hours of discussions not dissimilar to medieval theological debates" (John Mullen, "UK Popular Music and Society in the 1970s', Revue française de civilisation britannique $11 \mathrm{n}^{\circ} 3$ (2016)). Such groups would later be removed from the punk canon and be considered as new wave - a term usually used to refer to a wide array of artists who emerged in the wake of punk. Yet the terms punk rock and new wave were originally synonymous. Indeed, in 1976, Malcolm McLaren tried to impose the term new wave to describe the Sex Pistols, in reference to the New Wave of French cinema. (Jon Savage, England's Dreaming: Sex Pistols and Punk Rock (London, Faber \& Faber, 2005), p. 159).

45. Half way between variety entertainers and modern pop groups, showbands were groups of musicians who toured Ireland's dance halls and played covers of international pop hits in such a way that they were not perceived as transgressing traditional values Their heyday was the 1950s and 1960s but their popularity endured well into the 1970s. See Nuala O'Connor, Bringing It All Back Home: The Influence of Irish Music at Home and Oversea (Dublin, Merlin, 2001), p. 127.

46. Cette opposition à la culture américaine est à nuancer. Voir le chapitre sur le punk " pop ", 3.2.4.1.

47. Matthew, survey, 2017. Timothy Heron, 'Le punk en Irlande du Nord (1976-1983)', (PhD dissertation, University of Reims Champagne-Ardennes, 2017).

\section{ABSTRACTS}

Throughout the late 1970 s and early 1980s, at a time when cross-community contact was relatively uncommon in Northern Ireland, the punk subculture attracted both young Catholics and Protestants who temporarily set aside their political, religious and class differences. This set punks outside the mainstream of the wider culture. But not only did this behaviour mark them out, punk discourse sought to present the subculture as being anti-establishment and distant from the mainstream. This paper seeks to discuss some of the features of punk which enabled participants in Northern Ireland to deliberately cast themselves as outsiders, notably by discussing the role that the abject and horror played in distancing punk from the dominant culture and how this divergence from the mainstream was entrenched by constructing and maintaining strict boundaries between the punk subculture and the wider society.

À la fin des années 1970 et au début des années 1980, à une époque où les échanges intercommunautaires sont relativement rares dans l'Irlande du Nord des «Troubles ", la scène 
punk attire à la fois des jeunes catholiques et protestants qui, de manière temporaire, mettent de côté leurs différences politiques, religieuses et sociales. Ces interactions singulières placent les punks en opposition aux normes de la société nord-irlandaise, mais le discours punk lui-même cherche à présenter la sous-culture comme étant non-conformiste et éloignée du " mainstream ». Le présent article s'attache à analyser certaines caractéristiques du punk qui permettent aux membres de cette sous-culture de se présenter comme des marginaux, notamment en abordant les thématiques de l'abject et de l'horreur et de la place que ceux-ci jouent dans l'éloignement volontaire de la culture dominante et comment cette divergence est entérinée par la construction et le maintien de frontières strictes entre la sous-culture punk et le « mainstream ».

INDEX

Keywords: punk, horror, abject, Northern Ireland, popular culture, popular music

Mots-clés: punk, horreur, abject, Irlande du Nord, culture populaire, musique populaire

\section{AUTHOR}

\section{TIMOTHY HERON}

SEARCH (UR 2325), Université de Strasbourg

Timothy Heron is an associate professor at the University of Strasbourg. His PhD dissertation focussed on the punk subculture in Northern Ireland during the "Troubles". His wider interests lie with gender issues, popular music and alternative cultures. He is part of PIND ("Punk is not dead"), a research project on French punk funded by the National Agency for Research (ANR). 